\title{
THE SCHISTOSOMULA TEGUMENT ANTIGEN AS A POTENTIAL CANDIDATE FOR THE EARLY SEROLOGICAL DIAGNOSIS OF SCHISTOSOMIASIS MANSONI
}

\author{
Rafaella GRENFELL(1), Watson MARTINS(1), Vanessa SILVA-MORAES(1), Neusa ARAUJO(1), Edward OLIVEIRA(2), \\ Cristina FONSECA(1) \& Paulo Marcos Zech COELHO(1)
}

\begin{abstract}
SUMMARY
If Schistosoma mansoni infection could be detected in its early stages, especially before the egg deposition in the host tissues, the development of severe pathologic lesions could be efficiently prevented. We therefore developed an indirect enzyme-linked immunosorbent assay based on the detection of specific IgG against schistosomula antigens (ELISA-SmTeg). The assay was applied in sera samples from non-infected and infected mice collected seven and 15 days post-infection. The results were compared to the number of adult worms obtained by perfusion of the murine hepatic system 50 days post-infection. The sensitivity and specificity of the ELISA-SmTeg were $100 \%$ ( $p=0.0032$ and 0.0048 respectively for seven and 15 days of infection) with a cutoff value of 0.15 ( $p$ $=0.0002$ ). Our findings show a novel low-cost serological assay using antigens which are easy to obtain, which was able to detect all the infected mice as early as seven days post-infection.
\end{abstract}

KEYWORDS: Experimental approach; Acute schistosomiasis; Diagnosis; Immunological assay; Schistosomula antigens.

\section{INTRODUCTION}

As an important zoonosis, schistosomiasis remains a significant global public health problem. Approximately 200 million humans and a significant number of livestock are infected with schistosomes, and approximately 20 million patients suffer from severe complications ${ }^{18}$. Severe complications of schistosomiasis have been reported after only a few weeks of exposure ${ }^{13-15}$ and these patients are at a high risk of developing chronic manifestations with irreversible fibrosis ${ }^{17}$. Despite the public health importance of schistosomiasis and the risk that the disease might spread and intensify further in the absence of wide-ranging measures to improve it, schistosomiasis has been neglected for decades as a result of many consistent factors ${ }^{16}$. The most imperative factor which makes it difficult to control the spread of the disease is the absence of diagnostic methods capable of detecting the disease, especially in the pre-patent phase.

The host immune response to antigens excreted from embryonated mature eggs results in the formation of granulomas which lead to fibrotic changes in chronic infections ${ }^{19}$. In the majority of schistosome infections, the adult female worms start to discharge eggs 30 days post-infection, and the eggs can be seen in host liver tissues about five weeks postinfection. After six weeks, egg granulomas appear in the infected liver ${ }^{2}$. If schistosome infections could be detected before the egg deposition in the host tissues, chemotherapy could be effective and the development of severe pathologic lesions in host tissues could be prevented ${ }^{6,7}$. It is therefore imperative to have a straightforward, low-cost assay capable of detecting the initial phase of the infection, which can be used in the field and/or for the increasing number of travelers and the floating population.

The objective of the present study was to develop and test the capability of a novel assay which could serve as a potential candidate for the methodology in the early diagnosis of schistosomiasis mansoni. In order to do so, we used schistosomula tegument antigens in an enzyme-linked immunosorbent assay for the detection of specific $\operatorname{IgG}$ (ELISA-SmTeg). The performance of the assay was evaluated for murine schistosomiasis, particularly for seven to 15 days of infection. Nevertheless, it is still essential to evaluate the effectiveness of this assay for acute human schistosomiasis.

\section{MATERIALS AND METHODS}

Mice sera and perfusion of the hepatic portal system: Twenty-six female Swiss mice (4-6 weeks old) purchased at the Animal Facility of René Rachou Research Center/FIOCRUZ were each infected with 40 cercariae (standard deviation of \pm 10 ) of $S$. mansoni (LE strain) by the subcutaneous route ${ }^{11}$. Fifteen female Swiss mice were used as a negative control of infection. Serum samples were collected by retro orbital sinus puncture at days seven and 15 after infection (13 mice/group). After 50 days, the mice were sacrificed by cervical dislocation and submitted to

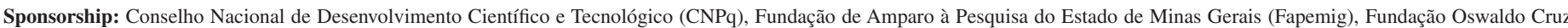
(Fiocruz)/Centro de Pesquisas Rene Rachou (CPqRR), Coordenação de Aperfeiçoamento de Pessoal de Nível Superior (Capes), The Council of the International Educational Exchange of Scholars (Fulbright, U.S. Department of State).

(1)Laboratório de Esquistossomose, Centro de Pesquisas René Rachou, Fundação Oswaldo Cruz (Fiocruz), 30190-002 Belo Horizonte, Minas Gerais, Brazil.

(2)Laboratório de Pesquisas Clínicas, Centro de Pesquisas René Rachou, Fundação Oswaldo Cruz (Fiocruz), 30190-002 Belo Horizonte, Minas Gerais, Brazil.

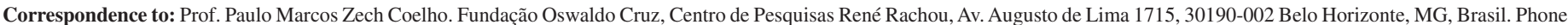
55313349 7740. E-mail: coelhopm@cpqrr.fiocruz.br 
GRENFELL, R.; MARTINS, W.; SILVA-MORAES, V.; ARAUJO, N.; OLIVEIRA, E.; FONSECA, C. \& COELHO, P.M.Z. - The schistosomula tegument antigen as a potential candidate for the early serological diagnosis of schistosomiasis mansoni. Rev. Inst. Med. Trop. Sao Paulo, 55(2): 75-8, 2013.

perfusion of the hepatic portal system using saline solution $(1.17 \% \mathrm{NaCl})$ and $50 \mathrm{U} / \mathrm{L}$ of heparin ${ }^{10}$. Adult worms were counted in a stereoscopic microscope (Zeiss Stemi DV4, Nettetal, GE). The use of animals was approved by the Commission for Ethics in the Use of Animals (CEUA FIOCRUZ), Brazil (L-02308).

Preparation of the $S$. mansoni schistosomula tegument antigen (SmTeg): Cercariae of the LE strain were obtained at the René Rachou Research Center/Fiocruz Laboratory of Malacology and were mechanically transformed into schistosomula using the technique described above, with some modifications ${ }^{12}$. In short, cercariae were placed into conical tubes and left in an ice bath for 30 minutes, before the centrifugation (Eppendorf Centrifuge 5820R, Hamburg, GR) at 200g for three minutes, at $4{ }^{\circ} \mathrm{C}$. The pellet was resuspended in cold Earle's salts and lactalbumin hydrolyzate medium (ELAC). The cercarial tails were broken in vortex (Scientific Industries Genie-2) at maximum speed for two minutes. Later the tails were removed from the medium through repeated washing steps with ELAC at $37{ }^{\circ} \mathrm{C}$, and schistosomula were incubated for 90 minutes at $37{ }^{\circ} \mathrm{C}$ and washed with $0.9 \%$ saline solution. This step was followed by centrifugation at $200 \mathrm{~g}$ for one minute. For tegument removal, $2 \mathrm{~mL}$ of $0.3 \mathrm{M}$ calcium chloride was added to the schistosomula that was stirred in vortex for seven minutes and centrifuged at $200 \mathrm{~g}$ for one minute. The supernatant was centrifuged at $50000 \mathrm{~g}$ for an hour and the pellet enriched with membrane was resuspended in $0.9 \%$ saline and dialyzed against $1.7 \%$ saline solution for 72 hours. Protein concentration was determined by the Bradford method ${ }^{3}$. The final concentration used in standardized tests was $0.52 \mu \mathrm{g} / \mu \mathrm{L}$.

Indirect Enzyme-Linked Immunosorbent Assay: Based on the technique described above ${ }^{9}$ with some modifications. In short, microtiter plates MaxiSorpTM Surface (NUNC Brand Products, Roskilde, DK) were coated with $100 \mu \mathrm{L}$ per well of SmTeg diluted at $1 \mu \mathrm{L} / \mathrm{mL}$ in buffer $0.05 \mathrm{M}$ carbonate-bicarbonate $\mathrm{pH} 9.6$ for 16 hours at $4{ }^{\circ} \mathrm{C}$. Next the plates were washed three times with $0.15 \mathrm{M}$ phosphate buffer saline $\mathrm{pH}$ 7.2 containing $0.05 \%$ of polysorbate sodium (LGC Biotecnologia, São Paulo, BR) (washing buffer). Then the free sites were saturated with 300 $\mu \mathrm{L}$ per well of $2.5 \%$ skim milk diluted in washing buffer, incubated at 37 ${ }^{\circ} \mathrm{C}$ for one hour. After further washing steps, $100 \mu \mathrm{L}$ of individual mice sera (diluted $1: 100$ ) in $0.15 \mathrm{M}$ phosphate buffer saline $\mathrm{pH} 7.2$ were added to the plates and were incubated at room temperature for one hour. The plates were submitted to washing steps and incubated at room temperature for one hour with anti-IgG conjugated to peroxidase diluted in washing buffer (anti-mouse IgG Fc specific-Southern Biotech, Birmingham, USA) at the dilution of 1:15000. Plates were washed again and $100 \mu \mathrm{L}$ of substrate solution (3,3',5,5-tetramethylbenzidine) (Invitrogen, Grand Island, USA) was added to each well. The enzymatic reaction was stopped after eight minutes of incubation in the dark by adding $50 \mu \mathrm{L}$ per well of $2 \mathrm{~N}$ sulfuric acid. The results were obtained as absorbance values at $450 \mathrm{~nm}$ in the microplate reader (BIORAD 3550, Tokyo, JA). The cutoff value of the ELISA-SmTeg for murine sera samples was $0.15(0.66 \pm$ 0.09 ), determined by the ROC curve (chart area $=1.0$ ).

Positive and negative controls were assayed properly, as well as wells without antigen and sera samples as a control of the nonspecific adsorption of conjugate. The standard dilution was determined by a dilution curve, performed with the same reagents and equipment based on six different dilutions.
Statistical analysis: Data deriving from absorbance values were analyzed with Minitab software (Minitab Inc, College, USA) by the Kolmogorov-Smirnov normality test. Normally distributed data were analyzed by the Student's $t$ test and non-normally distributed data were analyzed by the Mann-Whitney test ( $p<0.05$ as significance level). The sensitivity, specificity, cutoff values and likelihood ratios were determined with Prism 4.0 software.

\section{RESULTS}

The performance of ELISA-SmTeg was firstly evaluated with 41 mice sera samples, for which 26 mice were infected with 40 cercariae (standard deviation of \pm 10 ) of $S$. mansoni by the subcutaneous route. The results obtained in absorbance values were initially compared to the cutoff value of 0.15 , which was determined after a screening of all positive and negative samples and was based on $100 \%$ sensitivity and specificity, which was confirmed by the area of the ROC curve that reached the highest result of $1.0(\mathrm{~A}=1.0)$. Afterward, the results were compared to the number of worms obtained after the perfusion technique. The geometric mean estimated by the perfusion technique of the number of adult worms per mouse previously infected with 40 cercariae was 19.6 (standard deviation of \pm 5.7 ), and it corroborated the absorbance values found after the ELISA-SmTeg assay.

The results are shown in the Figure 1, and demonstrate that ELISASmTeg was capable of detecting specific IgG antibodies in all of the 26 sera samples from mice recently infected with $S$. mansoni (seven and 15 days after infection) with a cutoff value of $0.15(p=0.0002)$.

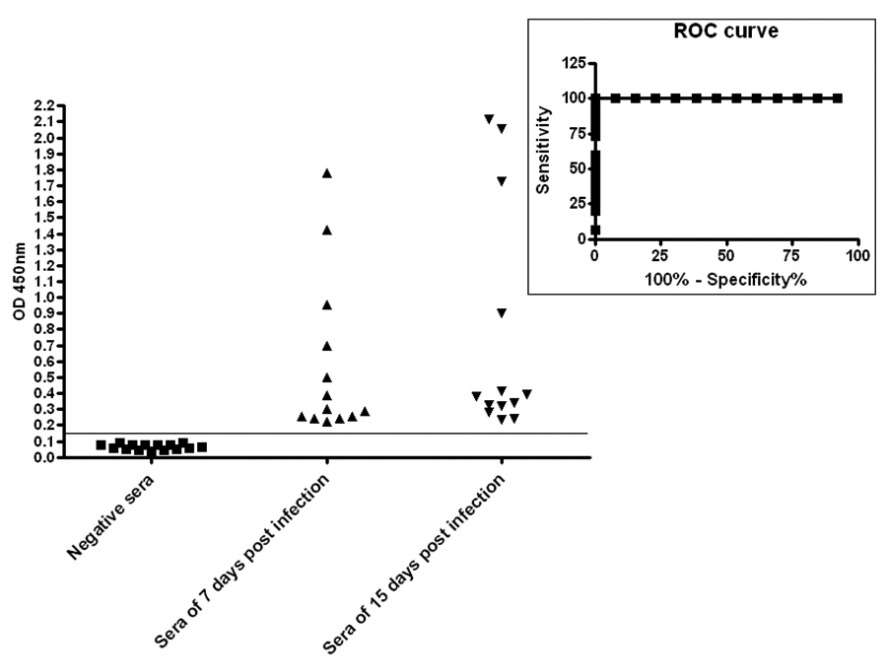

Fig. 1 - IgG levels detected in mice sera by ELISA-SmTeg. Mice were exposed to 40 cercariae of $S$. mansoni and serum samples were collected at seven and 15 days after infection. Each sample is represented by the mean of four absorbance values for two independent experiments. Cut off value are represented by bar. The box graphic indicates the ROC curve for $100 \%$ of sensitivity and specificity for mice sera.

From the Table 1, compared with the control at each time interval by $t$ test, a statistically significant increase appeared in the infected group on both days seven and 15 post-infection $(p=0.032$ and 0.048 respectively). The level of circulatory anti-SmTeg IgG in the infected 


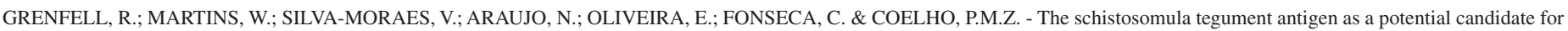
the early serological diagnosis of schistosomiasis mansoni. Rev. Inst. Med. Trop. Sao Paulo, 55(2): 75-8, 2013.

Table 1

The amount of circulatory IgG anti-SmTeg in mice sera at days 0,7 and 15 post-infection

\begin{tabular}{lccc}
\hline \multirow{2}{*}{ Groups } & Number of animals & The amount of circulatory IgG anti-SmTeg in mice sera (OD at 450 nm, mean \pm SD) \\
\cline { 3 - 4 } & 26 (13/group) & $0 \mathrm{dpi}$ & $7 \mathrm{dpi}$ \\
\hline $\begin{array}{l}\text { Infection } \\
\text { Control }\end{array}$ & 15 & $0.080 \pm 0.014$ & $0.580 \pm 0.096$ \\
$p$ value & & 0.032 & 0.0048 \\
\hline
\end{tabular}

$p$ value. Control group versus infected group. dpi $=$ days post infection.

mice group did not show an increasing trend within the period of infection analyzed, whereas no obvious change was found in the control group, and a significant difference was found between the infected mice group and the control group.

\section{DISCUSSION}

A good serological test for the diagnosis of schistosomiasis should be able to detect $S$. mansoni very early after the onset of infection. A tool is needed to solve the problem of differential diagnosis due to the non-specific symptoms of the early stages of the disease ${ }^{8}$, and doubly due to the possibility of treatment before the elimination of eggs during the pre-patent phase. In experimental hosts, anti-schistosome antibody reactivity remains low for worm antigens, until the infections become patent $^{1,5}$. This could be a result of the early stages of infection being poorly immunogenic, which in turn would help explain why a good test to diagnose pre-patent infections has not yet been developed.

This work addresses the development of an indirect immunological assay for the early diagnosis of human infection using schistosomula tegument antigens. The scope was based particularly on the exposure time to the schistosomula tegument in infected individuals before the onset of eggs by the parasite.

We evaluated the sensitivity/specificity of ELISA-SmTeg for the detection of specific titers of IgG using mice sera. Therefore, sera samples were collected from mice (40 cercariae) at day 7 and 15 after the subcutaneous infection. All mice groups were submitted to the perfusion technique for attainment of worms after 50 days of infection, when the parasite burden for each sample was established. We noticed that the ELISA-SmTeg was properly standardized and it was efficient to detect serum antibodies in mice, since there was a noticeable statistical difference between the antibody titers from infected and non-infected groups with a cut off value of $0.15(p=0.0002)$. It was possible to achieve total efficiency on the diagnosis of all samples with $100 \%$ sensitivity and specificity in light of the fact that all the negative and positive mice presented the accurate result, as shown by the ROC curve (Fig. 1).

Our data indicates that antigens from the schistosomula tegument may be a potential candidate for early diagnosis of infection with $S$. mansoni, which could be further developed into early serological diagnosis of human schistosomiasis mansoni. The levels of circulatory anti-SmTeg IgG in infected mice sera showed a statistically significant increase from day 7 and 15 post-infection in comparison to the mice sera prior to infection in the control group (Table 1). These results suggest that anti-SmTeg IgG could be detectable in the host at a very early stage, at least from day 7 after infection (Fig. 1), and this forms a basis for further studies.

From the Table 1, no fluctuation in circulatory anti-SmTeg IgG level in infected mice sera was observed from days 7 to 15 post-infection, showing that the anti-SmTeg IgG level was maintained throughout the period of schistosomula exposure. As a tegument extract of proteins, the extent of SmTeg antigens exposure may have been sufficient to stimulate the host to produce abundant specific IgG for keeping the continual rise until the eggs began to be trapped in tissues and developed to miracidium on day 35 of the infection.

It was anticipated that the difficulties associated with parasitological diagnosis might be overcome by adopting immunological methods ${ }^{4}$, especially when this diagnosis can be performed in the pre-patent phase, and this may provide evidence that an infection is present. An assay for measuring antibody activity before the eggs are laid could therefore provide useful information on the programs' effectiveness ${ }^{4}$. SmTeg is therefore a potential antigen for the early diagnosis of schistosomiasis. These findings provide a foundation for further studies, making this crude antigen an especially attractive target for widespread use in the prevention and control of schistosomiasis.

\section{RESUMO}

\section{Antígenos de tegumento de esquistossômulos são candidatos em potencial para o diagnóstico de fase aguda da esquistossomose mansoni}

A detecção da infecção pelo helminto Schistosoma mansoni quando realizada nas fases iniciais, especialmente antes da oviposição nos tecidos do hospedeiro, pode impedir de forma eficiente o desenvolvimento de graves lesões patológicas. Baseado nisto, foi desenvolvido um ensaio imunoenzimático indireto para detecção de anticorpos IgG específicos contra antígenos de esquistossômulos (ELISA-SmTeg). Este ensaio foi aplicado em amostras sorológicas de camundongos não infectados, da mesma forma que de camundongos recentemente infectados, após sete e 15 dias de infecção. Os resultados foram comparados com o número de vermes adultos obtidos por perfusão do sistema hepático murino 50 dias pós-infecção. A sensibilidade e a especificidade do novo método, denominado ELISA-SmTeg, foram de $100 \%$ ( $p=0,0032,0,0048$, respectivamente, durante sete e 15 dias de infecção) com um valor de corte de 0,15 ( $p=0,0002)$. Nossos resultados mostraram que um ensaio de baixo custo, que utiliza antígenos de fácil obtenção, é capaz de discriminar a esquistossomose mansoni em modelo experimental de forma precoce, incluindo sete dias pós-infecção. 
GRENFELL, R.; MARTINS, W.; SILVA-MORAES, V.; ARAUJO, N.; OLIVEIRA, E.; FONSECA, C. \& COELHO, P.M.Z. - The schistosomula tegument antigen as a potential candidate for the early serological diagnosis of schistosomiasis mansoni. Rev. Inst. Med. Trop. Sao Paulo, 55(2): 75-8, 2013.

\section{REFERENCES}

1. Ambroise-Thomas P, Andrews P. Development of fluorescent antibodies directed against larval stages, eggs, and adults of Schistosoma mansoni in mice harbouring unisexual or bisexual infections. Tropenmed Parasitol. 1976;27:483-8.

2. Barbosa MA, Pellegrino J, Coelho PM, Sampaio IB. Quantitative aspects of the migration and evolutive asynchronism of Schistosoma mansoni in mice. Rev Inst Med Trop Sao Paulo. 1978;20:121-32.

3. Bradford MM. A rapid and sensitive method for the quantitation of microgram quantities of protein utilizing the principle of protein-dye binding. Anal Biochem. 1976;72:248-54.

4. Doenhoff MJ, Chiodini PL, Hamilton JV. Specific and sensitive diagnosis of schistosome infection: can it be done with antibodies? Trends Parasitol. 2004;20:35-9.

5. Dunne DW, Bain J, Lillywhite J, Doenhoff MJ. The stage-, strain- and speciesspecificity of a Schistosoma mansoni egg antigen fraction (CEF6) with serodiagnostic potential. Trans R Soc Trop Med Hyg.1984;78:460-70.

6. Enk MJ, Lima AC, Drummond SC, Schall VT, Coelho PM. The effect of the number of stool samples on the observed prevalence and the infection intensity with Schistosoma mansoni among a population in an area of low transmission. Acta Trop. 2008;108:222-8.

7. Enk MJ, Amaral GL, Costa e Silva MF, Silveira-Lemos D, Teixeira-Carvalho A, Martins-Filho OA, et al. Rural tourism: a risk factor for schistosomiasis transmission in Brazil. Mem Inst Oswaldo Cruz. 2010;105:537-40.

8. Evengard B, Hammarstrom L, Smith CIE, Linder E. Early antibody responses in human schistosomiasis. Clin Exp Immunol. 1990;80:69-76.

9. Harlow E, Lane D. Antibodies: a laboratory manual. New York: Cold Spring Harbor Lab; Imperial Cancer Research Fund Laboratories; 1988.

10. Pellegrino J, Siqueira A. Técnica de perfusão para colheita de Schistosoma mansoni em cobaias experimentalmente infestadas. Rev Bras Malar Doenças Trop. 1956;8:589-97.
11. Peters PA, Warren K. A rapid method of infecting mice and other laboratory animals with Schistosoma mansoni: subcutaneous injection. J Parasitol. 1969;55:558.

12. Ramalho-Pinto FJ, Gazzinelli G, Howells RE, Mota-Santos TA, Figueiredo EA, Pelegrino J. Schistosoma mansoni: defined system for stepwise transformation of cercariae to schistossomule in vitro. Exp Parasitol. 1974;36:360-72.

13. Records of the Massachusetts General Hospital. Case 21-1985. A 21 year-old man with fever, diarrhea, and weakness of the legs during a sojourn in Kenya. Weekly clinico-pathological exercises. New Engl J Med. 1985;312:1376-83.

14. Shi GF, Xu ZY, Fu Q, Wen XH, Ma JY, Zhang JS. Dynamic study on relationship between serum SEAIC level and hepatic pathological changes in mice infected with Schistosoma japonicum. Zhongguo Ji Sheng Chong Xue Yu Ji Sheng Chong Bing Za Zhi. 1994;12:205-9.

15. Tarp B, Black FT, Petersen E. The immunofluorescence antibody test (IFAT) for the diagnosis of schistosomiasis used in a non-endemic area. Trop Med Int Health. 2000;5:185-91.

16. Utzinger J, Raso G, Brooker S, De Savigny D, Tanner M, Ornbjerg N, et al. Schistosomiasis and neglected tropical diseases: towards integrated and sustainable control and a word of caution. Parasitology. 2009;136:1859-74.

17. Warren KS, Boros DL, Hang LM, Mahmoud AA. The Schistosoma japonicum egg granuloma. Am J Pathol. 1975;80:279-94.

18. World Health Organization. Bruun B, Aagaard-Hansen J. The social context of schistosomiasis and its control: an introduction and annotated bibliography. Geneva: World Health Organization; 2008. Available from: http://dosei.who.int/uhtbin/cgisirsi/ tLEqou8myB/26990009/5/0.

19. Zhou X, Wu J, Huang X, Kunnon SP, Zhu X, Chen X. Identification and characterization of Schistosoma japonicum $\mathrm{Sjp} 40$, a potential antigen candidate for the early diagnosis of schistosomiasis. Diagn Microbiol Infect Dis. 2010;67:337-45.

Received: 16 April 2012

Accepted: 24 August 2012 